former wife. The chancellor was not satisfied that the petitioner had rebutted the principle of the permanence of Christian burial and, as the power to grant a faculty in such a case is discretionary, the faculty was refused. [WA]

doi:10.1017/So956618X09990251

\author{
Re St Mary, Ticehurst \\ Chichester Consistory Court: Hill Ch, February and March 2009 \\ Extension - consultation - public notice
}

The incumbent and churchwardens sought a faculty for the construction of an extension to a Grade II* listed church for a children's chapel, meeting room, kitchen facilities and toilet. Planning permission had been obtained. After a significant process of consultation the petitioners secured the support of English Heritage, the Victorian Society and the Church Buildings Council. At the consultation stage, the Society for the Protection of Ancient Buildings (SPAB) had expressed objections in writing, which had not been met in the final proposal. After a significant delay in presentation of the petition, the parish wrote to the registry seeking a swift determination. The chancellor was not prepared to adjudicate upon the petition without first ascertaining the views of SPAB. Rule 13(3) of the Faculty Jurisdiction Rules 2000 was of no application because, although SPAB had properly been consulted in a timely manner, the chancellor could not be satisfied that it had indicated that it had "no objection or comment to make' and in such circumstances the requirement for special notice was mandatory.

After the handing down of the written judgment and the issue of the faculty, the registrar received an objection from a parishioner who alleged that the public notice displayed in accordance with Rule 6 of the Faculty Jurisdiction Rules 2000 was not displayed in its entirety, in that the reverse of the notice - containing instructions on how to object to the proposed works - was not visible. The chancellor ordered an immediate stay on the implementation of the faculty pending inquiries. The investigation as to whether the notice was correctly displayed was inconclusive and the chancellor made no finding of fact in the matter. He noted that Rule 33 stated that non-compliance with the Faculty Jurisdiction Rules did not necessarily render a faculty void. He considered in some detail the nature and likely force of objections that the parishioner might have made and concluded that the objections would not have altered the outcome of the case. While mindful that a further period of notice might have produced additional and possibly different objections, the delay that this would have caused to the parish in the implementation of the works had also 
to be considered. Accordingly, he reinstated the faculty and gave permission to proceed. [RA/WA]

doi:10.1017/So956618X09990263

\section{Re St Peter, Draycott}

Court of Arches: Cameron, Dean; Gage and Bishop Chs, March 2009 Font - fixture or fitting - financial emergency - oral hearings - intervener status

The Victorian Society appealed against the decision of the Bath and Wells Consistory Court granting a faculty permitting the respondents to sell the font from a Grade II listed church. The sale was to be to a public body or by public auction and permission was granted to apply the funds therefrom to defray maintenance costs in respect of the church. The font had been in the church since its consecration. It was large and ornate and had been designed by the celebrated Victorian architect William Burges. The petitioners had been offered a significant sum from a private collector who wished to purchase the font. The parish's quinquennial inspection had revealed significant works required to maintain the church. The petitioners wished to use the proceeds of sale of the font to defray these and other maintenance costs. The Church Buildings Council (CBC) was permitted to intervene for the purposes of the appeal under Rule 24 of the Faculty Jurisdiction (Appeals) Rules 1998 and CPR 52.12A, it not having been a party at first instance.

The court rejected the argument that the chancellor should have held an oral hearing in this case. All parties (including the Victorian Society) had consented to a determination on written representations - thus it could not amount to a legitimate ground of appeal. The court held that

the dictum of the Deputy Dean in St Gregory, Tredington [1972] Fam 236 that 'faculties [for the disposal of items] should seldom if ever be granted without a hearing in open court' no longer carries the weight which it did in the past.

but had been superceded by the written representations procedure under Rule 26 of the Faculty Jurisdiction Rules 2000.

The court rejected the CBC's submission that the sacramental nature of a font meant that it could never be sold or disposed of to another use. In the absence of any evidence of whether the font was fixed to the floor of the church other than by its own weight, the court endorsed the chancellor's decision to apply both the 